\title{
Prospects of Green Marketing in Bangladesh: An Empirical Study on Green Marketing
}

\section{Md. Amimul Ehasan}

Lecturer, Department of Business Administration, Z. H. Sikder University of Science and Technology (ZHSUST), Shariatpur, BANGLADESH

Corresponding Contact:

Email: amimul_ehasan@yahoo.com

\begin{abstract}
The awareness of environmental degradation has been a long time coming to Bangladesh. In recent years, environmental issues in Bangladesh have received much attention, reflecting rising public concern and awareness of environmental problems. Pressure groups have been campaigning vigorously for the environment and media reporting on environmental issues has increased dramatically. It has also moved up on the agenda in political decision making and numerous laws and regulations were enacted for the protection of environment. Moreover, through the earth summit in Rio de Janeiro in 1992 and its follow-up summits in Berlin in 1995 and in New York in 1997, environmentalists have set targets for international co-operation and action. The paper identifies the particular segments of green consumers and explores the problems and opportunities that the green marketing businesses have in Bangladesh. It also examines the present trends of green marketing in Bangladesh and describes the reason why companies should adopt it. Further, it deals with the future of green marketing and concludes by studying consumer perception regarding green products in Bangladesh and also the business firm's perception analysis.
\end{abstract}

Key Words: Green Marketing, environment, products, consumer, green technology, green food

\section{INTRODUCTION}

The term "Green Marketing" came into prominence in the late 1980s and early 1990s. The American Marketing Association (AMA) held the first workshop on "Ecological Marketing" in 1975. The proceedings of this workshop resulted in one of the first books on green marketing entitled "Ecological Marketing". The Corporate Social Responsibility (CSR) Reports started with the ice cream seller Ben \& Jerry's. In 1987, a document prepared by the World Commission on Environment and Development defined sustainable development as meeting "the needs of the present without compromising the ability of future generations to meet their own need," this became known as the Brundtland Report and was another step towards widespread thinking on sustainability in everyday activity (Fuller, 1999). Two tangible milestones for wave of green marketing came in the form of published books, both of which were called Green Marketing (Ken Peattie, 1998). According to the author of "The New Rules of Green Marketing: Strategies, Tools, 
and Inspiration for Sustainable Branding," from an organizational standpoint, environmental considerations should be integrated into all aspects of marketing - new product development and communications and all points in between (Ottman, 1998). The holistic nature of green also suggests that besides suppliers and retailers, new stakeholders be enlisted, including educators, members of the community, regulators, and NGOs. We should balance environmental issues with primary customer needs. The past decade has shown that harnessing consumer power to effect positive environmental change is far easier said than done. The so-called "green consumer" movements in the U.S. and other countries have struggled to reach critical mass and to remain at the forefront of shoppers' minds. While public opinion polls which were taken since the late 1980s have shown consistently that a significant percentage of consumers in the U.S. and elsewhere profess a strong willingness to favor environmentally conscious products and companies, consumers' efforts to do so in real life have remained sketchy at best (Prothero, 1998). One of green marketing's challenges is the lack of standards or public consensus about what constitutes a writer on green marketing. In essence, there is no definition of "how good is good enough" when it comes to a product or company making green marketing claims. This lack of consensus-by consumers, marketers, activists, regulators, and influential people-has slowed the growth of green products, because companies are often reluctant to promote their green attributes, and consumers are often skeptical about claims. Despite these challenges, green marketing has continued to gain adherents, particularly in light of growing global concern about climate change. This concern has led more companies to advertise their commitment to reducing their climate impacts, and the effect this is having on their products and services (Makower, 2008).

\section{MeANing OF GREen}

An important aspect to clarify is the meaning of green. In this thesis, this terminology primarily refers to 'environmentally friendly',' but for many people, the word 'green' may suggest a range of different emotions and understandings'. Examined what 'green' means without the context of advertising, and concluded that for different people 'green' will relate to one or more of the following components:

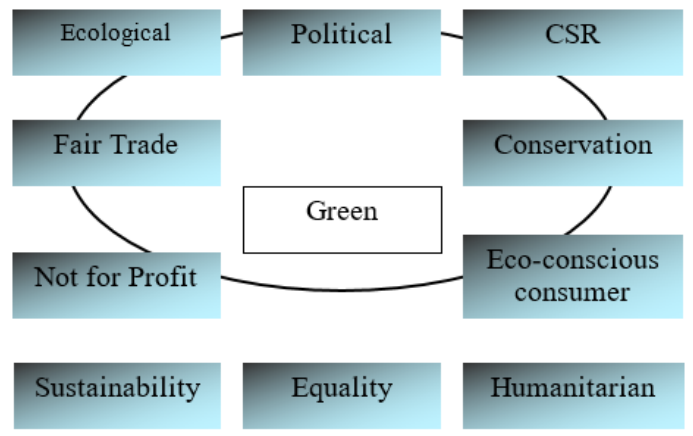

Figure 1: Prothero (1998), Environmental Marketing Management, p. 26.

Examination illustrates the numerous meanings of "green" for individuals, depending on their range of experience and perception (McDonagh, 1999). The main issue here, however, is the merging of social concerns with ecological concerns. In this study, terms such as green marketing, sustainable marketing, environmental marketing, are three different ways of terming the same subject, which is how companies can take care of the customer's interest and demand for their products or services while acting responsibly regarding its effects on the social and natural environment. Throughout this thesis, it will be used the term green marketing to cover this subject, though in quotations, the terminology used by the different authors will appear (McDonagh, 1999). 


\section{Why GREen MARKeting}

As resources are limited, and human wants are unlimited, it is for the marketers to utilize the resources efficiently without waste as well as to achieve the organization's objective. So, green marketing is inevitable. There is growing interest among consumers all over the world regarding the protection of the environment. Worldwide evidence indicates people are concerned about the environment and are changing their behavior. As a result of this, green marketing has emerged, which speaks for a growing market for sustainable and socially responsible products and services. Thus, the growing awareness among the consumers all over the world regarding the protection of the environment in which they live. People do want to bequeath clean earth to their offspring. Various studies by environmentalists indicate that people are concerned about the environment and are changing their behavior pattern to be less hostile towards it. Now we see that most of the consumers, both individual and industrial, are becoming more concerned about environment-friendly products. Green marketing was given prominence in the late 1980s and 1990s after the proceedings of the first workshop on Ecological marketing held in Austin, Texas (US), in 1975. Several books on green marketing began to be published after that. According to the Joel makeover (a writer, speaker, and strategist on clean technology and green marketing), green marketing faces a lot of challenges because of a lack of standards and public consensus on what constitutes "Green". The green marketing has evolved over some time. The evolution of green marketing has three phases. The first phase was termed as "Ecological" green marketing, and during this period, all marketing activities were concerned to help and provide remedies for environmental problems. The second phase was "Environmental" green marketing, and the focus shifted on clean technology that involved designing of innovative new products, which take care of pollution and waste issues. The third phase was "Sustainable" green marketing (Prothero, 1998).

\section{ObJectives OF the Study}

- To examine the prospect of a green market in Bangladesh.

- To analyze the impact of green marketing on the environment.

- To analyze the future of the green marketing.

\section{Data Collection Process}

The researcher used both qualitative and quantitative approaches for collecting data. The researcher collected data from primary and secondary sources. The researcher interviewed different customers, consumers, marketing officers, marketing research centers, companies, and industrialists.

\section{Sources of Data}

Primary source: Interview with different customers, consumers, marketing officers, companies, and industrialists.

Secondary source: Different books and articles, Evidence from the newspaper.

\section{Data Collection Instrument}

Questionnaire: Data was collected by questioning different customers, consumers, marketing officers, companies, and industrialists.

Sample Size and Structure: The survey was conducted on 100 people for a short time. 


\section{Positive Aspects of Green Marketing}

- First and foremost, a green marketing program is one that either adds renewable that would not already be added or supports renewable projects that might not otherwise continue to operate.

- A sign of a green marketing program is one that has strong links to local environmental groups, and that achieves broad support among regional and national groups with an interest in promoting green production.

- A green marketer that is seriously interested in greening the product will have a program that is linked to a larger vision and a strategic plan for making renewable an increasingly larger part of the production.

- For green marketing programs to be successful in the long run, they should both improve the environment and be fair to consumers. Prices should not be excessively higher than the actual cost of the resources in the portfolio (Fuller, 1999).

\section{Prospect and Initiates of Companies Green MARKeting in Bangladesh}

\section{UK firms look to Bangladesh to make green products}

Several firms from the United Kingdom are looking for forming ties with Bangladeshi companies to develop environmentally-sustainable goods and services. The number of UK firms interested to forge partnerships with Bangladeshi companies would be up to 20. These companies developed environmentally-sustainable technologies and services in areas ranging from energy, sea-food to waste, and flood management (McDonagh, 1999).

\section{Renewable Energy Technologies in Bangladesh}

Bangladesh stands at the cross-roads at the beginning of the 21st century. It has potential, but it must overcome many challenges, especially the challenges of global warming and energy crisis, to realize its full potential. Only $21 \%$ of the rural people are connected to the grid; even the urban people suffer from frequent load shading. Our industries are failing to get the power they need to function. We are in the front line of facing the threats of climate change. Our people are increasingly battered by cyclones and tornadoes. We are facing salinity, deforestation, drought, and bad weather. We need to change our living style, food habit and, especially adopt technology, which would help us to face the challenge of the climate change against this backdrop. I will talk about the potential of renewable energy technologies in Bangladesh. Renewable Energy can give us unlimited energy and, at the same time, protect us against the threat of climate change. Our Government is aware of the importance of renewable energy. That is why the target of meeting $10 \%$ of energy needs through renewable energy technologies by 2020 has been set. All VAT and taxes have been removed from solar panels. Bangladesh Bank has created a special fund of BDT 200 crores for facilitating not only ETPs, but also renewable energy technologies. Honorable Prime Minister Office will soon install solar home systems (McDonagh, 1999).

\section{Green Technology Takes a Leap}

The use of green technology showed a significant rise last year, covering some new areas from rural farming to city restaurants, corporate houses, and government offices. Industry insiders said a fall in prices of green technology-based products on the global market caused by recession has attracted more entrepreneurs to such business, which ultimately pushed the growth up. Infrastructure Development Company Ltd (IDCOL), a major financier for green technology in 
Bangladesh, says it receives at least five new proposals for green technology-based business every day. The installation of solar home systems increased to 17,000 per month in 2009 from around 10,000 a month in 2008. Solar irrigation pumps, water pumps, telecom base stations, and solar panels were the major hit last year. Experts termed the trend as a "hidden revolution." However, they suggested introducing a monitoring system to ensure the sustainability of such technology. According to IDCOL, the installation of solar home systems by 15 partner organizations increased to 421,202 until November 2009. The number was 300,000 in 2008 (Makower, 2008).

\section{Telecom Came to the Forefront to Go Green}

Bangladesh's largest mobile phone company Grameenphone is going for a transformation to become a 'green company' with a target to reduce 30 percent carbon emission by 2015 by installing solar base stations. The major change in the green technology market is that the local firms are increasingly opting for new solutions. Grameen Shakti and Rahimafrooz are developing telecom base stations. Rahimafrooz also industrialized solar pumps. The Prime Minister Office installed a solar power system to encourage people to go for green energy amid an acute power crisis. A similar move the Bangladesh Bank took in 2009 to set an example for banks. Nando's, a restaurant in Dhaka, installed a solar panel as a backup. The sustainability of such technology is crucial for Bangladesh, and so the government should introduce a monitoring system (Makower, 2008).

\section{Brick Kilns Going Green}

Bangladesh has started making bricks using new technology, which cuts carbon emission almost by half and creates scope for earning huge foreign currencies. Entrepreneurs and financiers said Bangladesh would be able to sell per tonne of saved carbon at \$15 after June 2010. Diamond Auto Bricks at Aduria Saughat in Narayanganj has set up such a brick kiln. On a visit, it was found that black fumes were coming out from the pipes of nearby brickfields, while Diamond Auto was making bricks without any black fumes seen around. The new technology being used by Diamond Auto and the likes is Hybrid Hoffman Kiln (HHK) technology imported from China. A single kiln that runs on HHK technology will produce 15 million bricks and cut carbon emission by 5,000 tonnes a year. A double unit kiln will produce 30 million bricks, and cut carbon dioxide (CO2) emission by 10,000 tonnes every year. Industrial and Infrastructure Development Finance Company Ltd (IIDFC) has so far funded four brick manufacturing units, including Diamond Auto Bricks, under the technology. Bangladesh has about 6,000 authorized brickfields and numerous illegal ones (Makower, 2008).

\section{Challenges in Green Marketing}

A company cans several challenges before marketing green in Bangladesh. Some of the challenges are mentioned below:

Need for Standardization: It is found that only 5\% of the marketing messages from "Green" campaigns are entirely true, and there is a lack of standardization to authenticate these claims. There is no standardization currently in place to certify a product as organic.

New Concept: Bangladeshi literate and urban consumer is getting more aware about the merits of Green products. But it is still a new concept for the masses. The consumer needs to be educated and made aware of the environmental threats. The new green movements need to reach the masses, and that will take a lot of time and effort.

Patience and Perseverance: The investors and corporate of Bangladesh need to view the environment as a major long-term investment opportunity, and the marketers need to look at the long-term benefits from the green movement. 
Avoiding Green Myopia: The first rule of green marketing is focusing on customer benefits, i.e., the primary reason why consumers buy certain products in the first place. Do this right, and motivate consumers to switch brands or even pay a premium for the greener alternative (Roberts, 1996b).

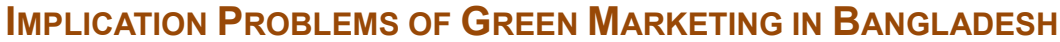

Some implication problems were found which are as follows:

- Neither customers nor producing organizations clearly state environmental benefits.

- There is no set of standard environmental characteristics which can be harmful for the customers or end-users.

- It is not clear to the general people that what kinds of benefits involve in environmentally friendly products.

- There has no legal authority that can make sure comparative differences between noenvironment friendly products and environmental products.

- Polluting manufacturing, e.g., all chemicals, dying, petroleum, and other waste outing organizations tried to respond to the misconceptions or fallacy or misleading notions presented by the media and pressure groups by offering their version of "facts" through public relations or promotional departments.

- Green marketing has been only implemented within the public relations department giving little room for product improvement or enhancement, and real environmental benefits.

- The similar products were produced, but some "new" benefits were added in their promotion to take advantage of the increasing interest customers showed in the environment.

- Green Marketing here was only concerned with promotional activity with modest or no attempt being made in products development in the context of green product.

- Greening sometimes led to a decrease in costs. While some products became cheaper; they were sold at best to provide the company with extra profit. When a further move towards sustainability meant increased costs, the companies were unwilling to spend, and greening was no longer such an attractive option.

- In recent times, all environment-friendly ordinance passed by the national assembly, but its implication program is going the very slowest way, which cannot help the product to be green (Shamsuddoha \& Alamgir, 2009).

\section{Golden Rules of Green Marketing}

- Know the Customer: Companies should make sure that the consumer is aware of and concerned about the issues that the product attempts to address.

- Being Genuine and Transparent: It means that (a) companies are actually doing what they claim to be doing in their green marketing campaign, and (b) the rest of their business policies are consistent with whatever they are doing that's environmentally friendly.

- Reassure the Buyer: Consumers must be made to believe that the product performs the job it's supposed to do-they won't forego product quality in the name of the environment.

- Consider Product Pricing: If the company charging a premium for the product-and many environmentally preferable products cost more due to economies of scale and use of higher-quality ingredients-make sure those consumers can afford the premium and feel it's worth it (Wicker, 1969). 


\section{Green Products and Its Characteristics}

Green product stresses the straight and tangible benefits provided by greener design, such as energy efficiency or recycled content, rather than emphasizing the environmental attributes them. Reducing the environmental impact of a product improves the product's overall performance and quality in ways that are important, not just the most dedicated and loyal green consumer, but to all consumers. It can be defined green products by the following measures:

- Products those are originally grown,

- Products those are recyclable, reusable and biodegradable,

- Products with natural ingredients,

- Products containing recycled contents, non-toxic chemical,

- Products that have eco-friendly packaging, i.e., reusable, refillable containers, etc. (Wicker, 1969)

\section{Designing Green Products}

The environment has become an increasingly important aspect of product design. There are various ways in which a product can be designed for environment. It can be changed in terms of:

- Contents: The manufacturer can green its product by switching to more sustainable components or ingredients or eliminating environmentally harmful substances.

- Manufacture: While products are normally designed to meet the requirements for performance in use, the green product may be changed to improve their eco-performance during manufacture.

- Performance: A car can be redesigned to improve the fuel performance of its engine or the impact resistance of its body (Roberts, 1996b).

\section{Competitive Advantages for Businesses}

In Bangladesh, a company can get four types of generic competitive environmental advantage strategy. Competitive advantage can be differentiation or lower costs, whereas the competitive focus can either be on organization process or product and services. The sustainable competitive focus and the possible source of competitive advantages will be determined by four factors in Bangladesh. They are:

- The structure of the industry.

- The company position in that industry.

- The types of markets the company serves.

- The firm's capabilities

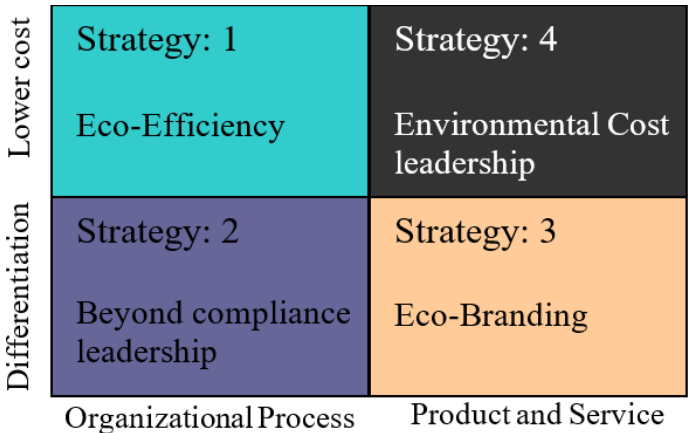

Figure 2: Factors of gaining competitive advantage 
Strategy 1: Eco-Efficiency: Firms that collectively need to reduce the cost and the environmental impact of the organizational process should select Strategy 1: Eco-efficiency. This is because cost reduction is crucial. The majority of companies that work on ecoefficiency strategies do so without a great deal of display and organizational process while decreasing the environmental impact and the costs associated with them (Wicker, 1969).

Strategy 2: Beyond Compliance Leadership: "Beyond compliance leadership" differs from eco-efficiency largely due to most companies within the Strategy 2 want their customers and the general public to know what they are attempting, i.e., their attempt to be green. "Beyond compliance leadership" basically means that the company goes the extra mile, giving them a first-mover advantage until the rest of the industry catches up, and it then becomes the norm (Wicker, 1969).

Strategy 3: Eco-Branding: Eco-branding is creating creditable green bran, often separate from a company's other product and brands. There are three basic rudiments for a company that wishes to use eco-branding to create a competitive advantage. The first rudiment is that the consumers must recognize a noticeable benefit for their purchase (Wicker, 1969).

Strategy 4: Environmental Cost Leadership: Acquiring a price premium may be the only option for some companies who offer ecologically orientated products. This is because 'being green' can cost more. The differentiation strategy may be the only way that the companies can pay off their ecological investments (Roberts, 1996b).

\section{Green Consumer SEgments For BANGLADESH}

In Bangladesh, the green consumers can be segment based on consumers' environmental attitudes, which is called "Shades of Green Segment."

True Blue Greens: This group in Bangladesh is characterized by consumers who committed hard core environmentalists who are highly involved in pro-environmental activities, and are often activists and leaders. They frequently interact with politicians and put pressure on environmental issues.

Greenback Greens: This group in Bangladesh is similar to the True blue. However, few Greenbacks are politically active. The most distinguishing characteristics of this group are that they are often willing to pay a premium price for an environmentally sound product.

Sprouts: This group does not usually purchase green products but are capable of doing so if they are marketed to them in an appropriate way. Furthermore, they tend to believe in environmental causes only in theory, not in practice. Despite this, they rank well above companies overall on when it comes to environmental requirements and standards. This makes the group a key swing group.

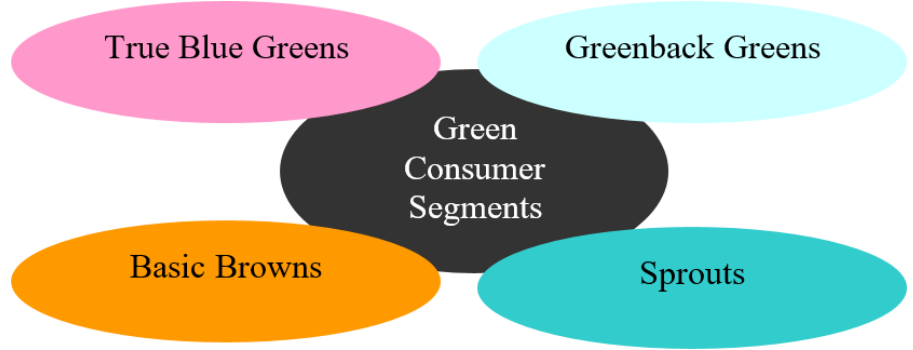

Figure 3: Consumer segments of green product 
Grousers: Grousers are usually not well versed in environmental issues and do not believe they are capable of effecting change. These consumers engage in a below-average amount of pro-environmental activities and requirement.

Basic Browns: These consumers are indifferent to environmental and social issues. Instead, they choose to focus on their everyday concerns, allowing these concerns to take up all of their time. They are not interested in making an effort to purchase a green product and do not see any benefit in doing so (Shamsuddoha \& Alamgir, 2009).

\section{DATA ANALYSIS AND FINDINGS}

According to Figure 4,73\% of the people surveyed are heard about the green product so, it can be said that a large number of people are aware of the green product in the capital city of Dhaka, but about $27 \%$ of the people are not conscious about it. So, marketers have the potentiality to make awareness about the green product and increase sells and identified the prospective customers.

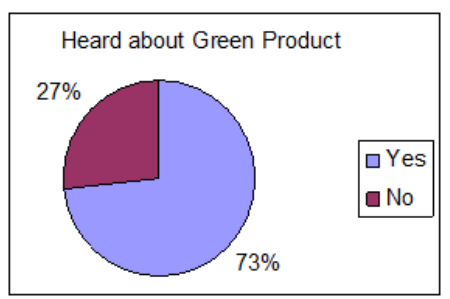

Figure 4: Percentage of people heard about green product

The definition of going green is "making conscious decisions to help protect the environment." It is presented in front of the respondent and about half of the respondent, 16 people, are agreed with the notion, 3 people is not agreed with this notion, and 11 people said that this definition is pretty close with their thought. This indicates that the business firms should value the perception of the consumers to better serve and successful.

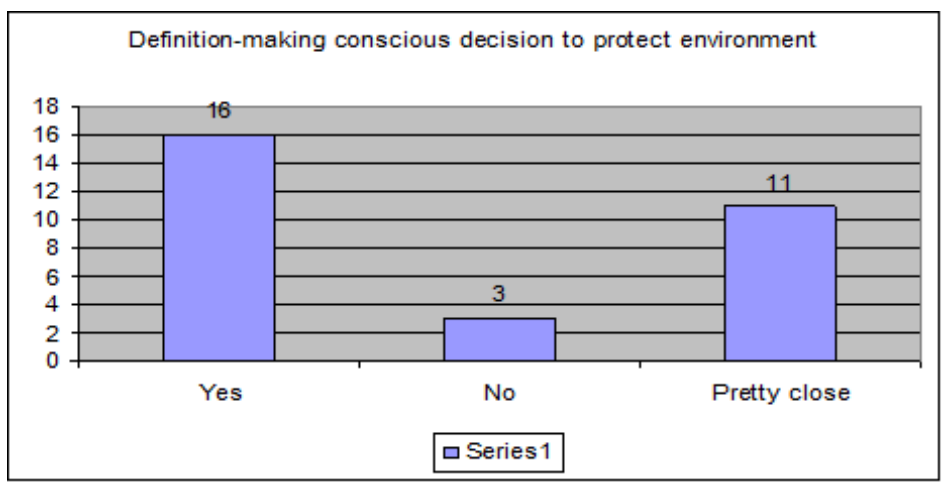

Figure 5: Definition-Making conscious decision to protect Environment

Although many people have heard about the green product, comprehension of the standard of green food differs from one to another. One respondent comprehends green food as green color, about 12 respondents comprehend as pesticide-free food, and 17 of the rest respondents comprehend green food as natural food. This indicates that a consumer comprehension on green food in Bangladesh differs. 


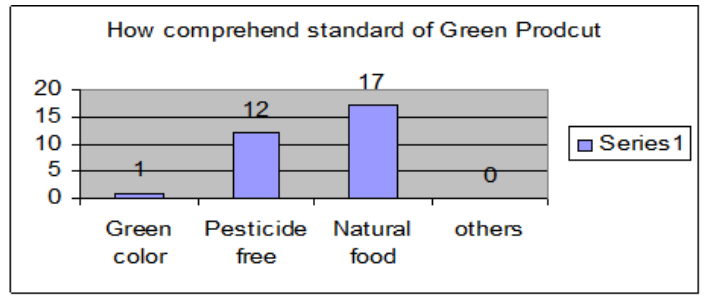

Figure 6: How comprehend the standard of green food

The Figure depicted that about 57 percent of the respondent ever bought green products and about 43 percent of the respondent never purchased any green products. This scenario has shown an opportunity to the business firms who want to go green and explore the consumers who do not ever buy green products.

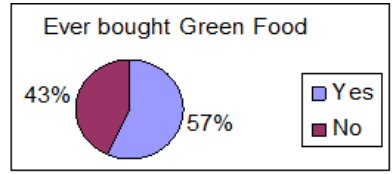

Figure 7: Ever bought green food

Although many people buy green products in Bangladesh, a great number of people also do not buy green products. Some reasons are identified in this research. Four people of the respondents are unsure about the green products, one person is uncertain about the quality of the green products, four people think that green products are too expensive, two people think that they did not need it, and the rest one respondent says that the store do not have green products. This situation expresses a confusing view on the green products among the consumers.

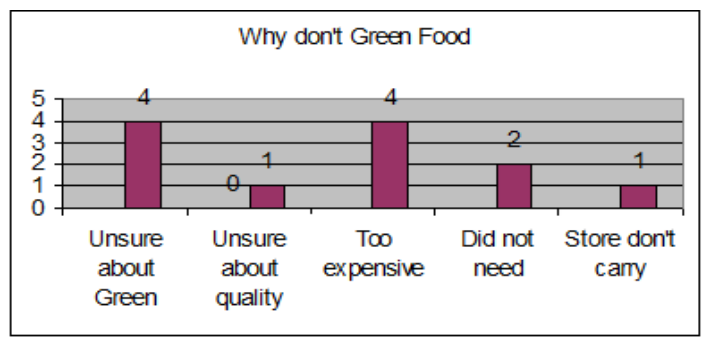

Figure 8: Why don't buy green food

The Figure 9 depicted that about 30\% of the respondent often know about the environmental reputation of the company, $37 \%$ people occasionally know the reputation of the company whose product he is purchasing, and 33\% people rarely know or try to know about the reputation of the company.

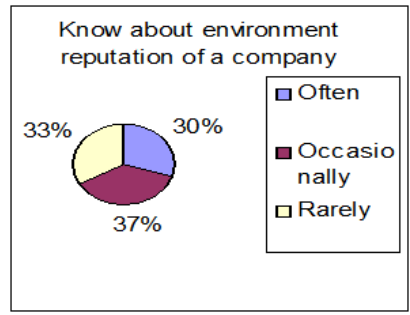

Figure 9: Know about environmental reputation of a company 
In the present world, the green-labeled food is sometimes viewed suspicious about quality. The survey depicted that $33 \%$ people trust in the green-labeled food and $10 \%$ people is not sure about the green-labeled food. So, marketers need to gain trust about the green label in Bangladesh.

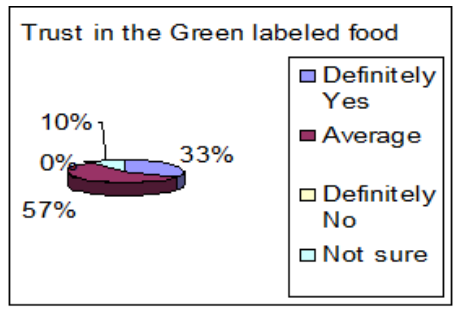

Figure 10: Trust in the green labeled food

In Bangladesh, the density of retail shops is very high and people go to retail shops regularly. About 36\% people think that green products are displayed in shops, and 37\% think that it is not displayed, and $27 \%$ do not notice any green products display. So, marketers need to focus on more exposure.

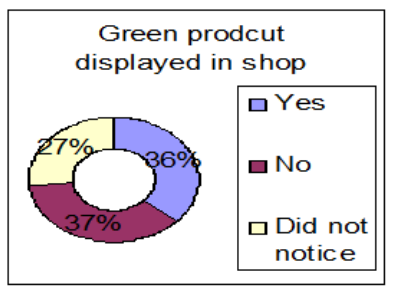

Figure 11: Green product displayed in shops

The figure 12 shows that the large portion of 12 respondents buy health and beauty of green products and the second-largest portion of 11 people buy meat, fish products of green products. So it may be a right opportunity for the marketer to select products for marketing in Bangladesh.

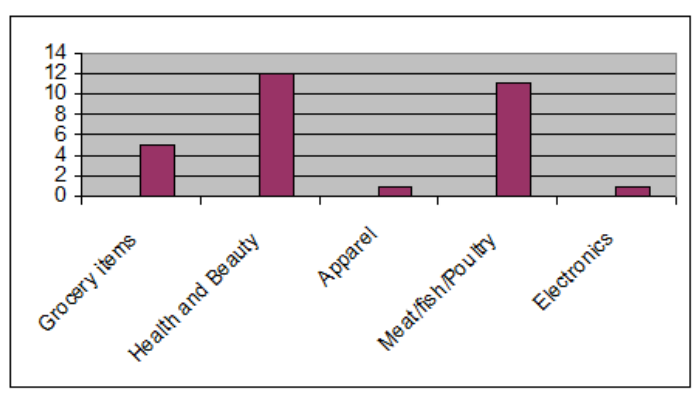

Figure 12: Buy any of the green products

Many activist groups, NGOs and governmental organizations are working for the environmental issues. The respondents think that the government and NGOs are doing good jobs for the environment, and 7 people think that the business firms are also doing well for the environment. 


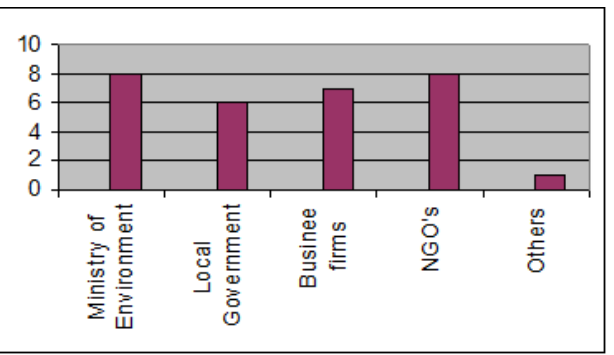

Figure 13: Doing good jobs for Environment

For increasing awareness of green products among the consumers, the respondents think that advertising and governmental support is most effective respectively 12 people think this opinion.

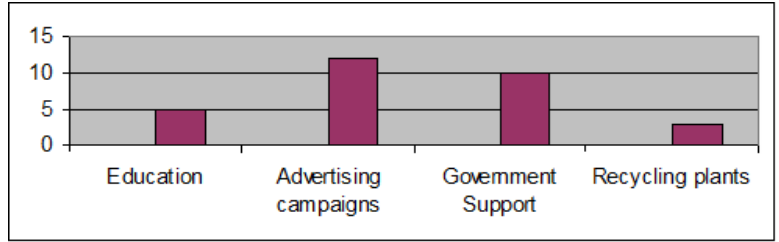

Figure 14: Steps for increasing awareness

$27 \%$ people predict that the green marketing will be successful in Bangladesh and a large portion of the respondents about $43 \%$ think that more companies will go green in the future in Bangladesh.

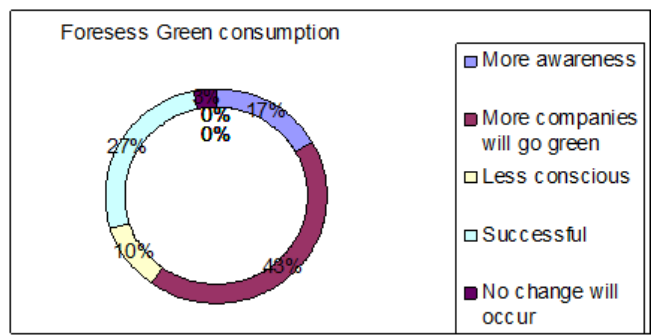

Figure 15: Foresees green consumption

\section{Recommendations for Realization of Green Marketing towards People}

Some recommendations for creating green awareness to consumers in Bangladesh is presented below:

In Bangladesh, it is needed to create some powerful or conscious citizen so that general people will follow them as an initiating person.

Government and concerned industry people have to take responsibility to make people understand about the importance of green products towards unconscious people like birth control issues.

CAB (Consumer Association of Bangladesh) should work the fastest way regarding various green issues and products. They should organize seminars, programs in media, newspaper, and give assurance to the customer that it is a green product. $\mathrm{CAB}$ should bargain with the Government, industrial, middlemen regarding green issues. 
Set live examples towards customer society like paper recycling and CNG so that people will start thinking it will be harmless, hazard-free, and environmentally friendly products for them. Realization based on availability or accessibility of greener products. In Bangladesh, "eco-tourism" was an unknown word for the local tourists, but few eco-park establishments in coastal belt and hilly areas had changed the scenario, and people start liking this kind of thing due to green.

Agencies should work on safety and quality matter of a product. In this process people will start keep faith on green activities? Green customers always make sure that they are safe and secure in the context of health and quality.

Firm's activities must follow environmental or green regulations or laws. Consumers' perception of green issues should be evaluated. Companies should see green marketing in terms of overall "Total Environmental Quality Management" within the organization. They should educate and inform all links in the value chain about green marketing, from producer and supplier to the end-user of a product or service. Link growing demand for green products to the following four " $E$ " factors such as easy - make it easy for customers to be green; empower customers - provide customers with solutions; enlist the support of customers; and establish credibility with all stakeholders of a business to guard against any form of backlash. Firms should use education-intensive point of sale displays, brochures, and packaging for its recycled shoes that make customers say, "These folks are for real."

Government and firms search for opportunities for recycled products. Several factors suggest the future for new products made from trash is bright. Green marketing is a different marketing concept than the traditional marketing model, and it is growing in importance in Bangladesh. Businesses and agencies must be responsive in implementing a green marketing policy, and the entire organizational structure must be involved in the process. In every sector, it is suffering from environmental hazards like chemical industry, petroleum-refining industry, garments, and packaging, and waste management. Now it is the right time to protect the environment from all hazards and convert all the environmental hazardous works into as environment-friendly works which can keep environment fresh for the next generation and similarly Bangladesh can able to establish green marketing issues in the consumer and organization mind so that green marketing can enhance marketability, improve product performance, protect environment hazard, protect health hazard, quality deterioration and represent a powerful new source of innovation. In this way, agencies can able to increase good realization in the customer mind. Businesses should invest in going green through their business operations and green marketing. Overall, this effort can help save the environment. In addition, companies will reap the benefits by gaining a stronger consumer base, increasing sales revenue, and gaining competitive advantage in their product category.

\section{CONCLUSION}

Now, this is the right time to select "Green Marketing" globally. It will come with a drastic change in the world of business if all nations make strict rules because green marketing is essential to save the world from pollution. From the business point of view, a clever marketer is one who not only convinces the consumer, but also involves the consumer in marketing his product. Green marketing should not be considered as just one more approach to marketing but has to be pursued with much vigor, as it has an environmental and social dimension to it. With the threat of global warming looming large, it is important that green marketing becomes the norm rather than an exception or just a fad. Recycling of paper, metals, plastics, etc., in a safe and environmentally harmless manner should become much more systematized 
and universal. It has to become the general norm to use energy-efficient lamps and other electrical goods. Marketers also have the responsibility to make the consumers understand the need for and benefits of green products as compared to non-green ones. In green marketing, consumers are willing to pay more to maintain a cleaner and greener environment. Consumers, industrial buyers, and suppliers need to pressurize effects on minimizing the adverse impacts on the environment. Green marketing assumes even more importance and relevance in developing countries like Bangladesh.

\section{REFERENCES}

Amin, M. R., Arif, I. and Rahman, M. M. (2012) “Green Marketing Practices for Sustainable Business Growth in Bangladesh: A Case Study of Dhaka City", Global Disclosure of Economics and Business, 1(2), pp. 96-102. doi: 10.18034/gdeb.v1i2.197.

Fuller, D. A. (1999). Sustainable Marketing: Managerial-Ecological Issues Thousand Oaks, CA: SAGE Publications, Inc. doi: 10.4135/9781452220611

Makower, J. (2008) Strategies for the Green Economy, McGraw-Hill, ASIN: B003P6B122

McDonagh, P. (1999), Green Marketing: Opportunity for Innovation, 2nd edn, by Jacquelyn A. Ottman, 1998. NTC, xviii + 270 pp, $\$ 24.95$ (hbk). ISBN 0-8442-32339-4. Bus. Strat. Env., 8: 147-148. doi:10.1002/(SICI)1099-0836(199903/04)8:2<147::AID-BSE191>3.0.CO;2-U

Padhy, P. C. and Mishra, A. K. (2018) "Green Consumerism: Catalyst for Environmental Marketing", Asia Pacific Journal of Energy and Environment, 5(2), pp. 49-52. doi: 10.18034/apjee.v5i2.252.

Prothero, A. (1998), Environmental Marketing Management: Meeting The Green Challenge by Ken Peattie, 1995. Pitman Publishing, $x+309$ pp, £36.00 (hbk) ISBN 027360279 9. Bus. Strat. Env., 7: 5253. doi:10.1002/(SICI)1099-0836(199802)7:1<52::AID-BSE136>3.0.CO;2-3

Roberts, J.A. (1996b), "Green consumers in the 1990s: profile and implications for advertising", Journal of Business Research, Vol. 36, No. 3, pp. 217 - 31.

Shamsuddoha, M., \& Alamgir, M. (2009). Application of Green Product Concept in Bangladesh. Department of Marketing, University of Chittagong, Bangladesh.

Straughan, R. and Roberts, J. (1999), "Environmental segmentation alternatives: a look at green consumer behavior in the new millennium", Journal of Consumer Marketing, Vol. 16 No. 6, pp. 558575. https:/ / doi.org/10.1108/07363769910297506

Wicker, A. W. (1969). "Attitudes versus action: The relationship of verbal and overt behavioral responses to attitude objects", Journal of Social Issue, 25(4), 41 -78.t

Yunus, M. and Rahman, M. T. (2014) “Green Marketing for Creating Awareness for Green Consumerism ", Global Disclosure of Economics and Business, 3(1), pp. 17-22. doi: 10.18034/gdeb.v3i1.167.

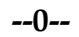

